\title{
Bacterial Contamination in Disposable Wet Wipes from General Restaurants
}

\author{
Moo Sang Chong \\ Department of Clinical Pathology, Cheju Halla University, Jeju 63092, Korea
}

\section{대중음식점 일회용 물티슈의 세균 오염도 조사}

\author{
정무상 \\ 제주한라대학교 임상병리과
}

\begin{abstract}
This study, funded by Jeju Special Self-Governing Province, evaluated the bacterial contamination in disposable wet wipes used in restaurants, coffee shops, and bakery shops. The materials used are 55 disposable wet wipes collected from general restaurants. The number of average bacteria found was $4.21 \times 10^{3} \mathrm{CFU} / \mathrm{mL}$ in 50 disposable wet wipes; in the other five disposable wet wipes, no bacterial contamination was found. The highest number of bacteria was measured as $16.67 \times 10^{3} \mathrm{CFU} / \mathrm{mL}$. Total bacterial count of separated are 71 strains. Among the 71 identified strains, 15 were Staphylococcus aureus and 3 were Pseudomonas aeruginosa. This can be an important problem. This study measured the level of bacterial contamination and identified the strains isolated in wet wipes. This study may be important as it provides the basis for establishing sanitation standars for wet wipes.
\end{abstract}

Key words: Bacterial contamination, Disposables, Restaurant, Wet wipe

This is an Open Access article distributed under the terms of the Creative Commons Attribution Non-Commercial License (http://creativecommons.org/licenses/by-nc/4.0) which permits unrestricted non-commercial use, distribution, and reproduction in any medium, provided the original work is properly cited.

Copyright () 2016 The Korean Society for Clinical Laboratory Science. All rights reserved.

. 
우 다양하다[4-6]. 상업적 형광증백제의 독성 및 환경 독성은 비교 적 광범위하게 연구되었으나, 인체의 영향은 이해되지 않고 있는 것이 현재의 상태이다. 국외의 대부분의 연구 결과로부터 발암성을 포함하여 인체에의 확실한 유해성이 확인된 경우는 거의 없다고 보 고되고 있다[7]. 위생처리업체를 거쳐 재활용이 되는 물수건의 경 우 규제방안과 인체의 유해성에 대한 평가가 이루어지고 있지만 일 회용 물티슈는 공산품으로 분류돼 유통기한 및 성분 표기 의무가 없으며 포장을 뜯기 전에는 어떤 상태인지 확인이 불가능한 실정이다.

1950년대 중반부터 유아가 있는 가정이나 보육시설, 노인복지 시설, 음식점, 병원 등에서 물티슈는 다양한 용도로 사용되어 왔다. 초기의 물티슈는 주로 여행 시 세척의 용도로 사용되었으나, 물티 슈는 유아의 피부세척, 화장이나 땀을 닦아내는 패드, 통증완화, 개 인위생, 애완동물관리, 건강관리, 공장에서 작업 중 피부에 부착된 오염물의 세척을 위해 사용되며 티슈 내에 첨가되는 성분에 따라 용도를 달리한다[8,9]. 이러한 일상생활과 밀접한 물티슈 중 대중 음식점에서 공급하는 물티슈는 대부분 중국에서 수입하고, 수개월 내지는 1 2년 보관하면서 사용하는 제품이며, 현재 논란이 되고 있는 가습기 살균제에서 문제가 되었던 성분인 보존제(방부제)와 계면활성제가 들어 있는 것으로 보고되고 있다[10].

현재 언론에서는 식품접객업소에서 소비자가 무상으로 사용하 는 '식당용 물티슈' 즉 보건복지부에서 공중위생관리법으로 관리 하고 있는 물종이류(식품접객업소등에서 물수건 대용 으로 사용하 는 물티슈에 한한다) 만을 일회용품규제대상에 포함시켜야 하며, 환경부에서는 규제완화 정책이나 물티슈 전체 시장을 의식하여 대 변하지 말고 '자원의 절약과 재활용 촉진에 관한 법률' 의 취지와 목 적에 의거 한번 사용 후 버리는 일회용품인 식당용 물티슈만을 '일 회용 규제 대상품목'에 추가로 지정하여 식당용 물티슈의 사용량을 억제함으로써 자원을 절약하고 환경 오염을 예방하는데 초점을 맞 춰야 한다고 주장하고 있다.

한국소비자원에서 2006년 업소용 위생용품 안전성 실태조사를 한 결과 식당 물티슈에서 일반세균이 허용기준 보다 최고 880 배 검 출되었다고 보고되고 있다[11]. 이에 본 연구는 대중음식점에서 제 공하는 일회용 물티슈에서 세균 오염도를 측정하고, 감염 질환의
원인이 될 수 있는 세균을 동정함으로써 대중음식점 등에 대한 위 생관리 감독 강화와 개선방안 및 일회용 물티슈의 위생관련 기준 마련에 기초자료를 제공하고, 개인 위생관리 및 국민보건 수준향상 에 기여 하고자 한다.

\section{재료 및 방법}

\section{1. 재료}

2016년 4월부터 6월까지 제주특별자치도에 위치한 대중음식 점, 커피전문점 및 제과 제빵점 등에서 제공하는 일회용 물티슈를 대상으로 미생물의 오염도를 평가하였다. 사용된 물티슈는 서로 다 른 대중음식점에서 공급하는 37 종류의 물티슈를 사용하였으며 18 종류의 물티슈는 2 매를 사용하여 총 55 매의 물티슈를 재료로 사용 하였다.

\section{2. 방법}

일회용 물티슈의 세균 수를 측정하기 위해 멸균된 컵에 물티슈 를 싸고 있는 비닐의 일부를 잘라내어 오염이 되지 않도록 1 회용 비 닐을 착용하여 물티슈의 양끝을 잡고 비틀어 $1 \sim 2 \mathrm{~mL}$ 의 액체를 채 취하여 검체로 사용하였다. 검체를 멸균된 일회용 $0.01 \mathrm{~mL}$ 정량백 금이를 이용하여 $0.03 \mathrm{~mL}$ 씩 혈액우무배지(Becton Dickinson, New Jersey, USA)와 맥콘키배지(Becton Dickinson, New Jersey, $\mathrm{USA}$ )에 접종하였으며, $35^{\circ} \mathrm{C}$ 배양기에서 18 시간 산소성 배양을 하 였다. 혈액우무배지와 맥콘키배지에 정량 배양한 세균을 집락계수 기를 이용하여 형성된 집락수로 생균수를 측정한 다음 희석배수를 곱하여 CFU/mL (CFU, colony forming unit)로 표시하였다(Fig. 1). 그리고 평판배지에 자란 집락 중에 그람염색과 카타라제 시험 을 하여 양성일 경우 혈액우무배지에 계대배양하고, 그람음성균은 맥콘키배지에 계대배양하였다. 이때 그람염색은 집락을 슬라이드 에 도말하여 건조시킨 후 염기성 색소인 crystal violet에 1분간 염 색한 후 흐르는 물에 수세하였다. 그 후 iodine 용액(Lugol's solution)에 1 분간 방치하여 매염을 한 후 수세하였다. 그 후 acetone-alcohol 용액으로 5 10초 탈색하여 수세하고 safranin

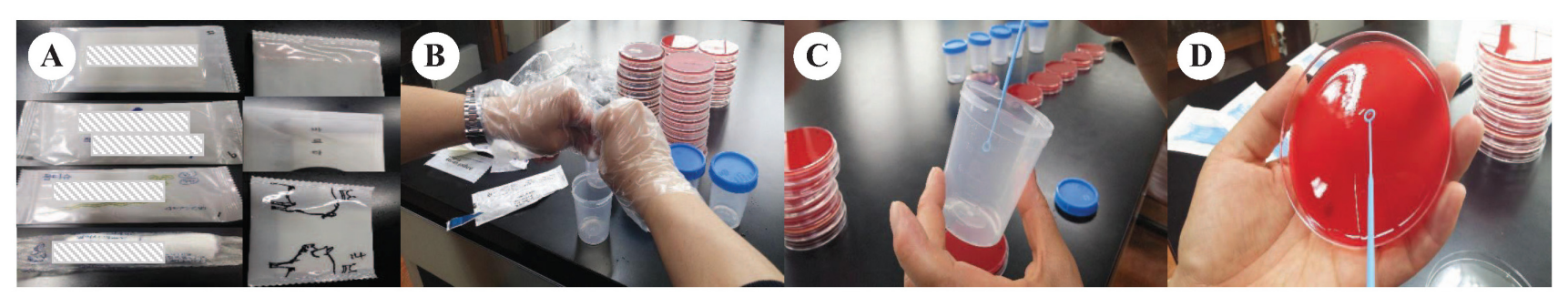

Fig. 1. Experimental method. (A) Disposable wet wipes. (B) Collection specimen. (C) Quantitative loop (0.03 mL). (D) Inoculation. 
$\mathrm{O}$ 용액으로 30초 염색 한 후 흐르는 물에 헹구고 건조시킨 다음 현 미경으로 관찰하였다. 배양된 균의 동정은 VITEK 자동화 동정기 (BioMérieux, Marcy l'Etoile, France)를 사용하였으며 사용된 동 정용 카드는 그람양성세균 동정용 카드(GPI)와 그람음성간균 동정 용 카드(GNI)를 이용하였다. 자료의 분석은 기술통계량으로 작성 하였다.

\section{결 과}

\section{1. 일회용 물티슈의 세균 수}

대중음식점 일회용 물티슈 55종의 평균 세균 수는 $4.14 \times 10^{3}$ $\mathrm{CFU} / \mathrm{mL}$ 이며, $0.00 \sim 0.09 \times 10^{3} \mathrm{CFU} / \mathrm{mL}$ 로 측정된 것은 10 종 (18.18\%), $0.10 \sim 0.99 \times 10^{3} \mathrm{CFU} / \mathrm{mL}$ 는 7종(12.73\%), 1.00 $1.99 \times 10^{3} \mathrm{CFU} / \mathrm{mL}$ 는 9종(16.36\%), $2.00 \sim 2.99 \times 10^{3} \mathrm{CFU} / \mathrm{mL}$ 는 7종(12.73\%), 3.00 3.99 $\times 10^{3} \mathrm{CFU} / \mathrm{mL}$ 는 4종(7.27\%), 4.00 $4.99 \times 10^{3} \mathrm{CFU} / \mathrm{mL}$ 는 5종(9.09\%), 5.00 9.99 $\times 10^{3} \mathrm{CFU} / \mathrm{mL}$ 는 6종(10.91\%), $10.00 \sim 16.99 \times 10^{3} \mathrm{CFU} / \mathrm{mL}$ 는 7종(12.73\%)으로

Table 1. Bacterial contamination levels in disposable wet wipes $\left(\times 10^{3} \mathrm{CFU} / \mathrm{mL}\right)$

\begin{tabular}{ccccc}
\hline Mean & S.D. & Variance. & Minimum & Maximum \\
\hline 4.14 & 4.82 & 23.21 & 0.00 & 16.67
\end{tabular}

Abbreviation: SD, standard deviation.

Table 2. The number of bacteria in disposable wet wipes

\begin{tabular}{ccc}
\hline $\begin{array}{c}\text { The number of bacteria } \\
\left(\times 10^{3} \mathrm{CFU} / \mathrm{mL}\right)\end{array}$ & $N$ & $\%$ \\
\hline$<0.09$ & 10 & 18.18 \\
$0.10 \sim 0.99$ & 7 & 12.73 \\
$1.00 \sim 1.99$ & 9 & 16.36 \\
$2.00 \sim 2.99$ & 7 & 12.73 \\
$3.00 \sim 3.99$ & 4 & 7.27 \\
$4.00 \sim 4.99$ & 5 & 9.09 \\
$5.00 \sim 9.99$ & 6 & 10.91 \\
$>10.00$ & 7 & 12.73 \\
Total & 55 & 100.00 \\
\hline
\end{tabular}

측정되었다. 5종(9.09\%)의 물티슈에서는 세균이 자라지 않았으며, 2 가지 이상의 세균 집락이 자란 검체는 21개(20.00\%)로 나타났다 (Table 1, 2).

\section{2. 일회용 물티슈의 세균 동정}

일회용 물티슈 55종 중 순수 분리한 총 세균 수는 71균주이며, 이 중 그람양성알균 49균주(69.01\%), 그람양성막대균 18균주 (25.35\%), 그람음성막대균 4균주 $(5.64 \%)$ 로 그람양성알균 균주가 월등히 높게 분포하고 있음을 알 수 있었다(Table 3). 그람양성알균 49균주 중 황색포도알균(Staphylococcus aureus) 15균주(21.13\%) 를 동정하였으며 나머지 균주는 코아귤라제-음성 포도알균 (coagulase-negative Staphylococci, CNS)이었다. 그람음성막 대균은 4균주중 3균주(4.23\%)가녹농균(Pseudomonas aeruginosa) 으로 동정되었으며, 1균주는 동정되지 않았다(Table 4, Fig. 2).

\section{고 찰}

최근 대중음식점에서 공급하는 일회용 물티슈 오염에 대한 관심 이 부각되고 있으며, 특히 위생 물수건을 재활용 할 때 사용되는 형

Table 3. Gram staining results of bacteria in disposable wet wipes

\begin{tabular}{ccc}
\hline Results & N & $\%$ \\
\hline Gram positive cocci & 49 & 69.01 \\
Gram positive bacilli & 18 & 25.35 \\
Gram negative bacilli & 4 & 5.64 \\
Total & 71 & 100.00 \\
\hline
\end{tabular}

Table 4. Genus/species of bacteria identified in disposable wet wipes

\begin{tabular}{lcc}
\hline \multicolumn{1}{c}{ Bacteria } & N & $\%$ \\
\hline Staphylococcus aureus & 15 & 21.13 \\
Coagulase-negative Staphylococci & 34 & 47.89 \\
Pseudomonas aeruginosa & 3 & 4.23 \\
Unidentified & 1 & 1.41 \\
Total & 53 & 74.66
\end{tabular}
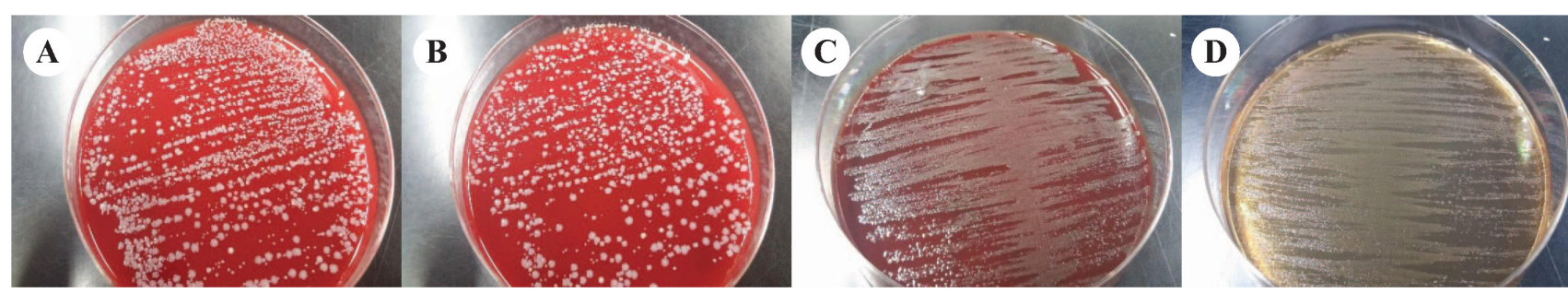

Fig. 2. Bacteria growth in disposable wet wipes. (A) Staphylococcus aureus (BAP). (B) Staphylococcus aureus (BAP). (C) Pseudomonas aeruginosa (BAP). (D) Pseudomonas aeruginosa (MaC). Abbreviation: BAP, blood agar plate; MaC, MacConkey agar. 
광증백제에 대한 인체의 유해성 부분은 민감한 반응을 보이고 있 다. 2006년 소비자안전센터 생활안전팀의 업소용 위생용품 안전 성 실태조사에 따르면 대중음식점에서 제공하는 물티슈와 물수건 에 대한 미생물 시험검사 결과, 조사대상 54 개 업소 중 33개 업소 (61.1\%)에서 일반세균이 검출되었으며, 식당 물티슈에서 일반세 균이 허용기준 보다 최고 880 배 검출되었고 검출된 세균 수는 $8.1 \times 10^{3} \sim 2.2 \times 10^{6} \mathrm{CFU} / \mathrm{g}$ 로 '위생용품의 규격 및 기준' 등에 명 시된 허용기준 $\left(2,500 \mathrm{CFU} / \mathrm{g}, 1.0 \sim 1.5 \times 10^{5} \mathrm{CFU}\right.$ 이하/장)보다최 저 3.2배, 최고 880배를 초과한 것으로 보고되었으며[11], 일반음 식점인 한식당의 위생평가를 실시한 결과 총 176 개의 시료에서 총 세균 수측정 결과 $200 \mathrm{~cm}^{2}$ 의 단위면적 당 검출되지 않은 것에서부 터 $2.14 \times 10^{9} \mathrm{CFU} / 200 \mathrm{~cm}^{2}$ 의 수치가 관찰되었고, 대장균군인 경 우는 검출되지 않은 것에서부터 $8.34 \times 10^{7} \mathrm{CFU} / 200 \mathrm{~cm}^{2}$ 의 수치 가 검출되었다고 보고하였다[12].

외식문화의 증가와 국제교류의 증가, 식품산업의 다국적화 등으 로 인해 식품오염과 식품 변질의 위험이 증가하면서 식중독은 발생 현황은 지속적으로 증가하고 있다[13,14]. 최근 5년간 우리나라의 식중독 발생 통계를 보면 연평균 발생 건수는 274 건, 연평균 발생 환자 수는 6,561명이었고, 원인 시설 별 발생 건수는 2014년을 기 준으로 학교 급식소가 51건(14.7\%), 기업체 급식소가 15건(4.3\%), 음식점이 213 건(61.0\%)으로 음식점에서의 식중독 발생 건수가 급 식소에서 발생한 건수보다 많았다. 하지만 식중독 발생 건수당 환 자수를 살펴보면 학교 급식소가 81.1명/건, 기업체 급식소가 25.3 명/건, 음식점이 8.3명/건으로 급식소가 음식점보다 식중독 발생 건수당 환자수가 더 많다고 보고하였다[15].

이에 본 연구는 대중음식점에서 제공하는 일회용 물티슈에서 세 균오염도를 측정하고, 감염 질환의 원인이 될 수 있는 세균을 동정 함으로써 대중음식점 등에 대한 위생관리 감독 강화와 개선방안 및 일회용 물티슈의 위생관련 기준 마련에 기초자료를 제공하기 위한 목적으로 진행하였다. 대중음식점 일회용 물티슈 55종의 평균 세 균 수는 $4.14 \times 10^{3} \mathrm{CFU} / \mathrm{mL}$ 이었으며, 세균이 자라지 않은 물티슈 는 5종이었다. 가장 높게 측정된 세균 수는 2 종의 물티슈에서 $16.67 \times 10^{3} \mathrm{CFU} / \mathrm{mL}$ 이상으로 나타났다. 순수 분리한 총 균수는 71균주이며, 이 중 그람양성알균 49 균주 중 황색포도알균 15 균주 (21.13\%)를 동정하였으며 나머지 34 균주는 응고효소-음성 포도 알균이었다. 그람음성막대균은 4균주 중 3균주(4.23\%)가 녹농균 으로 동정되었으며, 1 균주는 동정되지 않았다. 대중음식점에서 제 공하는 일회용 물티슈에서 황색포도알균과 녹농균이 발견되었다 는 점은 주목할 만 하다.

황색포도알균은 화농성 감염과 패혈증 등을 유발할 수 있고[16], 여러 가지 장관내독소 등을 분비하기 때문에 식중독, 원내 감염 및
지역 감염 등관 관련되어 큰 문제를 일으킬 수 있으며, 특히 항생제 의 과잉처방으로 인하여 꾸준하게 메치실린에 대한 항생제 내성 균 주가 증가하여 메치실린 내성황색포도알균(methicillin resistant Staphylococcus aureus)은 임상에서 일상적인 검사의 대상이 되 었으며[17], $\mathrm{Kim}$ 등[18]의 연구에 의하면 대학생의 필수 소지품인 휴대전화로부터 MRSA 균주의 분리율이 $37.2 \%$ 에 달해 병원감염 과 지역사회 감염의 위험요소로서 중요성이 부각되고 있는 세균으 로 보고되고 있다. 녹농균은 사용할 항균제가 상당히 제한적인 다 제내성균이며, 악성종양이나, 중증화상환자, 그 외 선행질환이 있 거나 스테로이드 또는 면역억제제, 항암제, 방사선 치료 등으로 숙 주의 저항력이 약화되는 여러 인자가 작용하면 발병이 촉진되어 치 명적이라는 점에서 병원감염관리와 환자 관리에 집중적인 관리가 되어야 하는 세균으로 보고되고 있으며[19,20], 국내에서도 카바 페넴 내성 균주가 점차 증가하고 있어 더욱 심각한 문제가 되고 있 다[21].

산업통상자원부 국가기술표준원, 환경부, 식품의약안전처는 관 계부처 협의를 거쳐 세정제, 방향제 등의 생활화학용품은 2015년 4월부터 환경부가, 인체청결용 물티슈는 2015년 7월부터 식품의 약품안전처가 화장품류로 관리한다고 밝혔다[22]. 그러나 본 연구 에 사용된 물티슈의 경우 대중음식점에서 사용되는 일회용품으로 현재 관리 감독 기관이 미비한 실정이다. 이에 최근 보도된 기사에 의하면 식당에서 쓰는 일회용 물티슈는 조만간 식품의약품안전처 가 소관 부처로서 관리기준을 따로 마련하고 안전관리를 강화할 예 정이라 밝혔다. 업체에서 고객을 대상으로 흔히 제공해 주는 물티 슈는 한 번 사용 후 버리는 일회용품이지만 정확한 보관방법 안내 가 없고 제조일과 사용기한 표시가 없는 제품이 대부분인 상황이라 수개월 내지 수년 간 보관하면서 사용하고 있는 실정이다. 이에 본 연구는 일회용 물티슈의 정확한 위생관련 기준 마련에 기초자료를 제공하고자 하며, 대중음식점 등에 대한 위생관리 감독 강화와 개 선방안 및 개인 위생관리를 철저히 하여 국민보건 수준향상에 기여 하고자 한다.

\section{요 약}

2016년 4월부터 6월까지 제주특별자치도에 위치한 대중음식 점, 커피전문점 및 제과 제빵점 등에서 제공하는 일회용 물티슈를 대상으로 미생물의 오염도를 평가하였다. 사용된 재료는 일회용 물 티슈 55종을 사용하였다. 대중음식점 일회용 물티슈 55종의 평균 세균 수는 $4.14 \times 10^{3} \mathrm{CFU} / \mathrm{mL}$ 이었으며, 세균이 자라지 않은 물티 슈는 5종이었다. 가장 높게 측정된 세균 수는 2 종의 물티슈에서 $16.67 \times 10^{3} \mathrm{CFU} / \mathrm{mL}$ 이상으로 나타났다. 순수 분리한 총 균수는 
71균주이며, 이 중 황색포도알균(Staphylococcus aureus) 15균 주, 녹농균(Pseudomonas aeruginosa) 3 균주를 동정하였다. 이는 대중음식점에서 공급하는 물티슈의 세균 오염도가 심각하다는 것 을 반영하며 기회감염의 원인이 되는 Staphylococcus aureus와, Pseudomonas aeruginosa가 발견된 것은 주목할 만하다고 볼 수 있다. 본 연구를 통해 한 번 사용 후 버리는 일회용품이며, 수개월 내 지는 1 2년 보관하면서 사용하는 제품인 일회용 물티슈의 위생관 련 기준 마련에 기초자료를 제공하고 대중음식점 등에 대한 위생관 리 감독 강화와 개선방안 및 개인 위생관리 및 국민보건 수준향상 에 기여 하고자 한다.

\section{Acknowledgements: None}

Funding: None

Conflict of interest: None

\section{References}

1. Choi MK. An analysis of groups with diet problems associated with dining out. Korean J Food \& Nutrition. 2008;21(4):536544.

2. Kim SA, Jo HY. A study on the eating out behavior patterns of youth: Junior high and senior high school students from different regions. Korean J Food Culture. 2004;19(3):336-347.

3. Shin JS, Park SH. Survey on bacteriological contamination of restaurants in Seoul area. Korean J Sanitation. 1986;1(1):41-46.

4. Signh N. Membrane technology in optical brightener production. Filtration and Separation. 1999;36(9):38-39.

5. Ma D, Carter RD, Haefner D, Dogariu A. The influence of fine kaolin and ground calcium carbonates on the efficiency and distribution of fluorescence whitening agents (FWA) in paper coating. Nordic Pulp and Paper Research Journal. 2008;23(3): 327-332.

6. Jiang D, Chen L, Fu W, Qiu H. Simultaneous determination of 11 fluorescent whitening agents in food-contact paper and board by ion-pairing high-performance liquid chromatography with fluorescence detection. J of Separation Science. 2015;38(4):605-611.

7. Kim JS, Choi DJ, Lee DJ, Sim JK, Jin DS, Shin YS, et al. Survey of exposure of the fluorescent whitening agent related products [cited 2016 July 28]. Available from: http://library.nier.go.kr/ search/DetailView.ax?cid=5566375.

8. Horovitz B. More consumers whip out wet wipes [cited 2016 July 28]. Available from: http://usatoday30.usatoday.com/money/ covers/2002-07-11-wipes.htm.

9. Seo JH, Lee DJ, Lee MK, Oh DH. Studies on the antibacterial ac- tivity of wet-tissue saturated with electrolytic water of $\mathrm{NaCl}$ solution. Journal of Korea TAPPI. 2015;47(6):147-153.

10. Yoo HJ, Hwang HS, Song EG. A Study on the improvement for safe consumption of wet tissue -Focusing on consumer's subjective safety assessment and labeling condition-. Journal of Safety and Crisis Management. 2014;10(8):81-97.

11. Korea consumer agency. Survey of safety for commercial use hygiene products (Paper napkins, wet tissues, wet towels) [cited 2016 July 28]. Available from: http://www.kca.go.kr/brd/ m_46/view.do?seq= 576\&srchFr $=\&$ srchTo $=\&$ srchWord $=\&$ srchT p=\&itm_seq_1=3\&itm_seq_2=0\&multi_itm_seq=0\&company_cd=\&company_nm=\&page $=26 \#$ report_tab01.

12. Jeong DK. Microbiological evaluations on the facilities and utilities of Korean restaurants. J Korean Soc Food Sci Nutrition. 2005;34(10):1611-1618.

13. Altekruse SF, Cohen ML, Swerdlow DL. Emerging foodborne diseases. Emerg Infect Dis. 1997;3(3):285-293.

14. Bae HJ, Chun HJ. Microbiological hazard analysis of cooking utensils and working areas of foodservice establishments and hygienic improvement by implementing HACCP system. Korean J Food Cookery Sci. 2003;19(2):231-240.

15. Ministry of Food and Drugs Safety. Statistics of foodborne illness outbreaks [cited 2016 July 28]. Available from: http:// www.foodsafetykorea.go.kr/portal/healthyfoodlife/foodPoisoningStat.do?menu_no=519\&menu_grp=MENU_GRP02.

16. Park SY, Son JS, Oh IH, Choi JM, Lee MS. Clinical impact of methicillin-resistant Staphylococcus aureus bacteremia based on propensity scores. Infection. 2011;39(2):141-147.

17. Nam HM, Lee AL, Jung SC, Kim MN, Jang GC, Wee SH, Lim SK. Antimicrobial susceptibility of Staphylococcus aureus and characterization of methicillin-resistant Staphylococcus aureus isolated from bovine mastitis in Korea. Foodborne Pathog Dis. 2011;8(2):231-238.

18. Kim CH, Lee JY, Kim MK, Kim SH, Park GY, Bae SY, et al. Isolation rate of methicillin-resistant Staphylococcus aureus (MRSA) from nasal cavity inferior regions and cellular phones. Korean J Clin Lab Sci. 2012;44(3):118-123.

19. Shin HS, Park YB, Cho KJ. Isolation frequency and antimicrobial susceptibility of Pseudomonas species from clinical materials. Korean J Clin Lab Sci. 2007;39(3):167-177.

20. Joklik WK, Hilda PW, Amos DB, Wilfert CM. Zinsser microbiology. 20th ed. New York: Appleton \& Lange; 1992. p576-583.

21. Yong D, Choi YS, Roh KH, Kim CK, Park YH, Yum JH, et al. Increasing prevalence and diversity of metallo- $\beta$-lactamases in Pseudomonas spp., Acinetobacter spp., and Enterobacteriaceae from Korea. Antimicrob Agents Chemother. 2006;50(5):18841886.

22. Ministry of Trade, Industry \& Energy. Life chemical goods and wet wipes department management changes [cited 2016 July 28]. Available from: http://www.kats.go.kr/mobile/content.do? cmsid=482\&skin=/mobile/\&mode=view\&page=13\&cid=17248. 